\title{
PERANCANGAN APLIKASI GUEST SELF SERVICE MENGGUNAKAN TEKNOLOGI QR CODE UNTUK MELAKUKAN ABSEN DI PT. MITRA INTEGRASI INFORMATIKA BERBASIS WEB
}

\author{
Ezra Inti Prasetya \\ Fakultas Teknologi Informasi, Program Studi S1 Teknik Informatika \\ Universitas Kristen Satya Wacana \\ Email: $\underline{672016032 @ \text { student.uksw.edu }}$ \\ Magdalena Ariance Ineke Pakereng \\ Fakultas Teknologi Informasi, Program Studi S1 Teknik Informatika \\ Universitas Kristen Satya Wacana \\ Email: ineke.pakereng@uksw.edu
}

\begin{abstract}
ABSTRAK
Penelitian ini mengusulkan sebuah aplikasi self service untuk melakukan pendataan tamu dan karyawan. Dalam melakukan absen pada aplikasi yang dirancang menggunakan QR Code sebagai pengenal orang yang melakukan absen. Proses absensi dilakukan oleh karyawan dengan melakukan scan terhadap QR Code yang dikirimkan melalui email. Aplikasi ini dikembangkan berbasis web dengan memanfaatkan teknologi Java, JavaScript, MySQL, Framework Spring Boot dan library Zxing dalam proses pembuatan dan pembacaan QR Code. Berdasarkan hasil pengujian yang dilakukan kepada developer dan pengguna aplikasi, dapat disimpulkan bahwa aplikasi Guest Self Service untuk absen berbasis web ini dapat berfungsi dengan baik serta dapat menyelesaikan permasalahan yang ada.
\end{abstract}

Kata kunci: self service, barcode, library zxing, springboot

\section{ABSTRACT}

This study proposes a self service application to collect data from guests and employees. In making absences in applications that are designed to use QR Code as an identifier for people who are absent. The attendance process is carried out by employees by scanning a QR Code sent by email. This application is developed based on web using Java technology, JavaScript, MySQL, Framework Spring Boot and Zxing library in the process of making and reading QR Code. Based on the results of tests conducted to developers and application users, it can be concluded that the Guest Self Service application for web-based absences can function properly and can solve existing problems.

Keywords: self service, barcode, library zxing, springboot

\section{PENDAHULUAN}

Self service adalah suatu sistem kerja atau konsep suatu perusahaan atau toko dimana para pelanggannya menikmati produk atau jasa dari toko tersebut tanpa dilayani oleh pelayan maupun staff dari perusahaan atau toko tersebut, melainkan para pelanggan melayani diri mereka sendiri [5].

QR Code adalah kode matriks atau barcode dua dimensi yang berasal dari kata "Quick Response", dimana isi kode dapat diuraikan dengan cepat dan tepat. QR Code dikembangkan oleh Denso Wave, sebuah perusahaan Jepang yang dipublikasikan pada tahun 1994. Dibandingkan dengan kode batang biasa, QR Code lebih mudah dibaca oleh pemindai dan mampu menyimpan data baik secara horizontal maupun vertical .

PT. Mitra Integrasi Informatika (MII) adalah anak perusahaan PT Metrodata Electronis, Tbk yang menjalankan jasa teknologi informasi dan komunikasi di berbagai sektor industri maupun UKM sebagai solusi kepada pelanggan, seperti tahap desain dan blue print, konsultasi, implementasi, dukungan, 
pemeliharaan, managed service dan pelatihan. Dalam menjalankan usaha, MII melakukan penyeleksian sumber daya manusia (SDM) agar dapat memenuhi kriteria atau spesifikasi yang diharapkan oleh tiap divisi.

Maka dari itu, dibutuhkan aplikasi berbasis web yang dapat menunjang kebutuhan untuk mendata karyawan dan kandidat karyawan yang datang ke APL tower. Pada saat ini, proses pendataan karyawan yang datang masih dilakukan secara manual sehingga dalam penggunaannya sering ditemukan kendala yang dapat menimbulkan inefisiensi dan miss communication dalam menjalankan tugas, seperti dalam melakukan pendataan tamu, karyawan maupun kandidat karyawan yang datang masih di lakukan secara manual. Ketika staff HRD hendak melakukan interview, staff HRD tersebut tidak dapat mengidentifikasi kandidat karyawan yang bersangkutan sudah tiba atau belum. Ketika staff HRD hendak melakukan renewal contract, staff HRD tersebut tidak dapat mengidentifikasi karyawan yang bersangkutan sudah tiba atau belum. Maka dari itu, berdasarkan latar belakang diatas secara khusus Aplikasi Guest Self Service merupakan jawaban dari kebutuhan MII.

Pada penelitian Mukhamad Taqwa Nuddin (2015) yang berjudul "Sistem Absensi Asisten Dosen Menggunakan QR Code Scanner Berbasis Android Pada Program Studi Sistem Informasi Universitas Muria Kudus" membahas tentang sistem aplikasi absensi dengan menggunaan metode pengembangan model waterfall, perancangan menggunakan UML, bahasa pemrograman yang digunakan yaitu PHP dan Android dengan Database My SQL [4].

Pada penelitian Akhiruddin Pulungan (2019) yang berjudul "Pemanfaatan QR Code dalam Memudahkan Proses Absensi Siswa Berbasis Aplikasi Mobile" membahas tentang perancangann sebuah sistem absensi yang dapat dilakukan menggunakan smartphone android dengan memanfaatkan sistem kamera untuk membaca QR Code [6].

Pada penelitian Riski Tuloli (2018) yang berjudul "Aplikasi Absen Kuliah Menggunakan Kode QR (Quick Response)" membahas tentang pereancangan sebuah aplikasi absensi mahasiswa menggunakan kode QR berbasis android di Politeknik Gorontalo. Dengan aplikasi tersebut dosen dapat melakukan absensi mahasiswa melalui kode QR yang tertera pada kartu mahasiswa menggunakan smartphone android sebagai pembaca kode QR, sehingga dosen tidak perlu lagi mencatat absensi mahasiswa [10].

Pada penelitian Farhan Ishami (2018) yang berjudul "Pengembangan Sistem Self-Service Reservation pada Everyday Smart Hotel Malang Menggunakan Customer Relationship Management (CRM) Operasional Modul Sales Force Automation dan Service Automation" membahas penerapan metode Customer Relationship Management Operasional modul Sales Force Automation dan Service Automation aktivitas Customer Self-Service yang bertujuan untuk meningkatkan pelayanan dan kepuasan pelanggan dengan menerapkan sistem informasi berbasis web yang terintegrasi sehingga waktu yang dibutuhkan lebih efisien [7].

Pada penelitian Chrismanto Eka Prastio (2018) yang berjudul "Aplikasi Self Service Menu Menggunakan Metode Scrum Berbasis Android" membahas perancangan aplikasi self service menu berbasis android pada Warkobar Cafe Cikarang dengan menggunakan salah satu metode pengembangan Agile, yaitu Scrum dan analisis yang dilakukan dengan survei pada sistem yang berjalan serta pengumpulan data untuk mendapatkan informasi yang dibutuhkan [9].

Pada penelitian Adi Nuryanto (2016) yang berjudul "Pembuatan Self-Service System di Dapoer Cha Cha Resto" membahas tentang membuat sistem swalayan di Dapoer Cha Cha Resto. Sistem yang dibuat memungkinkan pelanggan untuk memesan menu, langsung tanpa harus dilayani oleh seorang pramusaji. Sistem tersebut dirancang dengan teknik drag-and-drop sehingga menarik dan mudah bagi calon pengguna [3].

Berdasarkan beberapa penelitian yang telah membahas mengenai QR Code dan Self Service maka disusunlah penelitian terkait dengan Self Service untuk mengelola pendataan tamu dan karyawan serta implementasi framework Spring Boot. Berbeda dari penelitian sebelumnya, pada penelitian ini akan dibangun sebuah aplikasi berbasis web yang menggunakan framework Spring Boot berupa landing page yang lebih user friendly.

\section{METODOLOGI PENELITIAN}

Metodologi yang digunakan pada project Guest Self Srvice adalah Scrumban dimana metodologi ini menggabungkan metodologi Scrum dan Kanban. Berikut ini merupakan penjelasan dari metode Scrum dan Kanban yang dapat dilihat pada gambar 1. 


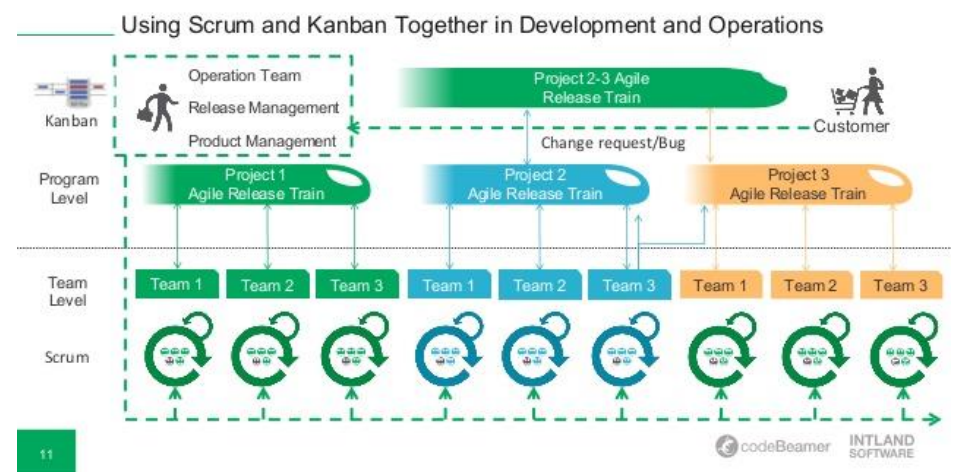

Gambar 1. Scrum dan Kanban (slideshare.net, 2016)

Menurut Azhari, S N Scrum merupakan salah satu varian dari metode agile yang iteratif dan incremental. Satu iterasi pada Scrum disebut dengan Sprint, dimana untuk setiap akhir dari Sprint produk yang sesuai dengan definisi "Done" harus diraih. Kedua pendekatan pengembangan software ini sama-sama menekankan pada pentingnya komunikasi dan kolaborasi antar berbagai pihak dengan tujuan untuk menghasilkan sebuah produk yang deliverable dan useable dengan menganalisa beberapa kasus yang telah ada [1].

Menurut Yoshiro Monden metode Kanban yaitu suatu kartu perintah produksi yang berfungsi untuk mengontrol persediaan, bentuk kanban adalah semacam "kartu vinil segi empat" yang dimasukkan ke dalam kantong plastik transparan dan ditempatkan pada billboard. Metode kanban produksi diterapkan dengan merencanakan aliran Kanban yang efisien [2].

\begin{tabular}{|c|c|c|c|c|c|c|c|}
\hline & & \multicolumn{2}{|l|}{ SPRINT-19 } & $2-S e p-19$ & $30-\operatorname{Sep}^{-19}$ & 21 & \\
\hline 1 & Overview & Guest Self Service Phasel & Medium & $2-$ Sep-19 $_{1}$ & 2-Sep-19 & 2 & Done \\
\hline 2 & Business Analyst & \begin{tabular}{|l|} 
Guest Self Service Phasel \\
\end{tabular} & Medium & 3-Sep-19 & $6-S_{e p}-19$ & 4 & Done \\
\hline 3 & System Analyst & Guest Self Service Phase I & Medium & 3-Sep-19 & $6-$ Sep $^{-19}$ & 4 & Done \\
\hline 4 & Front End & \begin{tabular}{|l|} 
Guest Self Service Phasel \\
\end{tabular} & Medium & $9-$ Sep-19 $_{1}$ & $20-$ Sep$_{-19}$ & 10 & Done \\
\hline 5 & BackEnd & Guest Self Service Phase I & Medium & 9-Sep-19 & $20-$ Sep-19 & 10 & Done \\
\hline 6 & Quality Assurance & Guest Self Service Phase I & Medium & $23-$ Sep-19 & $25-$ Sep-19 & 3 & Done \\
\hline 7 & User Acceptance Test & Guest Self Service Phase I & Medium & $26-$ Sep-19 & $30-$ Sep $^{-19}$ & 3 & Done \\
\hline 8 & Deployment & \begin{tabular}{|l|} 
Guest Self Service Phase \\
\end{tabular} & Medium & $30-$ Sep-19 & $30-$ Sep-19 $^{2}$ & 1 & Done \\
\hline \multirow[t]{2}{*}{9} & Golive & Guest Self Service Phasel & Medium & $22-$ Nov-19 & $22-$ Nov-19 & 1 & Done \\
\hline & & \multicolumn{2}{|l|}{ SPRINT-20 } & $1-0 \mathrm{ct}-19$ & $31-0 \mathrm{ct}-19$ & 13 & \\
\hline 1 & Overview & Guest Self Service Phase II & Medium & $1-0 \mathrm{ct}-19$ & $2-0 \mathrm{ct}-19$ & 2 & Done \\
\hline 2 & Business Analyst & \begin{tabular}{|l|l} 
Guest Self Service Phase II \\
\end{tabular} & Medium & $2-0 \mathrm{ct}-19$ & $4-$ Sep $^{-19}$ & 3 & Done \\
\hline 3 & System Analyst & Guest Self Service Phase ll & Medium & $2-0 \mathrm{ct}-19$ & $4-\operatorname{Sep}^{-19}$ & 3 & Done \\
\hline 4 & Front End & Guest Self Service Phase II & Medium & $7-0 \mathrm{ct}-19$ & $22-\operatorname{Sep}^{-19}$ & 12 & Done \\
\hline 5 & BackEnd & Guest Self Service Phase II & Medium & $7-0 c t-19$ & $22-$ Sep-19 & 12 & Done \\
\hline 6 & Quality Assurance & \begin{tabular}{|l|l|} 
Guest Self Service Phase II \\
\end{tabular} & Medium & $23-0 \mathrm{ct}-19$ & $25-$ Sep-19 & 3 & Done \\
\hline 7 & User Acceptance Test & Guest Self Service Phase II & Medium & $28-0 \mathrm{ct}-19$ & $31-0 c t-19$ & 4 & Done \\
\hline 8 & Deployment & Guest Self Service Phase II & Medium & $31-0 \mathrm{ct}-19$ & $31-0 \mathrm{ct}-19$ & 1 & Done \\
\hline \multirow[t]{2}{*}{9} & GoLive & Guest Self Service Phase ll & Medium & $22-$ Nov-19 & $22-$ Nov-19 & 1 & Done \\
\hline & & \multicolumn{2}{|l|}{ SPRINT-21 } & 1-Nov-19 & $15-$ Nov-19 & 11 & \\
\hline 1 & Overview & Guest Self Service Phase III & Medium & $1-$ Nov-19 & 1-Nov-19 & $\ddot{1}$ & Done \\
\hline 2 & Business Analyst & Guest Self Service Phase III & Medium & $4-N o v-19$ & 5-Nov-19 & 2 & Done \\
\hline 3 & System Analyst & Guest Self Service Phase III & Medium & 4-Nou-19 & 5-Nov-19 & 2 & Done \\
\hline 4 & Front End & Guest Self Service Phase III & Medium & 6-Nou-19 & 8-Nov-19 & 3 & Done \\
\hline 5 & Back End & Guest Self Service Phase III & Medium & $6-$ Nou-19 & 8-Nov-19 & 3 & Done \\
\hline 6 & Quality Assurance & Guest Self Service Phase III & Medium & $11-$ Nov-19 & 11-Nov-19 & 1 & Done \\
\hline 7 & User Acceptance Test & Guest Self Service Phase III & Medium & 12-Dec-19 & 14-Dec-19 & 3 & Done \\
\hline 8 & \begin{tabular}{|l|} 
Deployment \\
\end{tabular} & \begin{tabular}{|l|l|} 
Guest Self Service Phase III \\
\end{tabular} & Medium & 15-Nov-19 & 15-Nov-19 & 1 & Done \\
\hline 9 & GoLive & \begin{tabular}{|l} 
Guest Self Service Phase III \\
\end{tabular} & Medium & 22-Nou-19 & $22-$ Nov-19 & 1 & Done \\
\hline
\end{tabular}

Gambar 2. Timeline Project Guest Self Sevice

Timeline Project Guest Self Service memiliki 4 Story Points diantaranya: Invitation, Presence, Package Delivery dan Meet Employee di mana bagian tersebut merupakan Sprint 19, Sprint 20 dan Sprint 21 yang pekerjaannya dikerjaan secara iterative.

Perancangan sistem dibuat menggunakan Use Case dan Business Process Diagram (BPD) yang dapat digunakan untuk memetakan alur kerja sehingga penulis dapat memahami, menganalisa dan membuat perubahan positif pada alur kerja atau proses tersebut. 


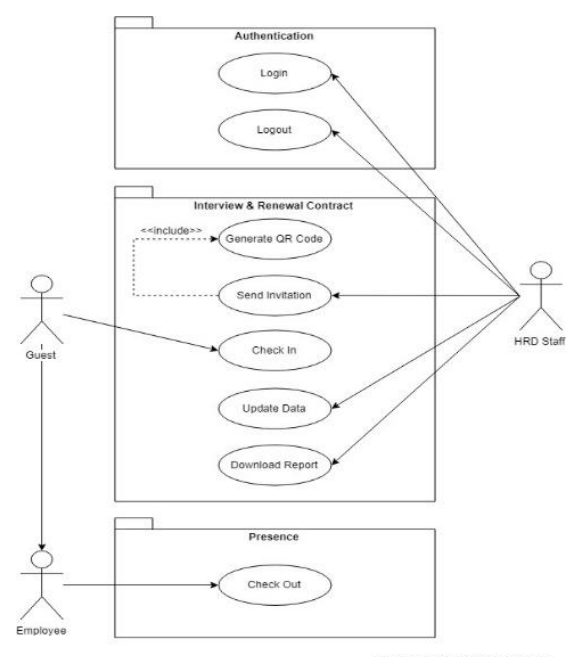

Gambar 3. Use Case Diagram Guest Self Service

Use case diagram berfungsi juga untuk menggambarkan kebutuhan pengguna sistem. Berdasarkan Gambar 3 terdapat tiga pengguna pada Guest Self Servie yaitu ada guest, HRD staff dan employee. staff HRD memiliki 5 fungsi utama yaitu login, logout, send invitation, update data dan download report. Pada fungsi send invitation dapat generate invitation menjadi bentuk QR Code. Guest memilki 1 fungsi utama yaitu check in. Sedangkan employee memiliki 1 fungsi utama yaitu check out.

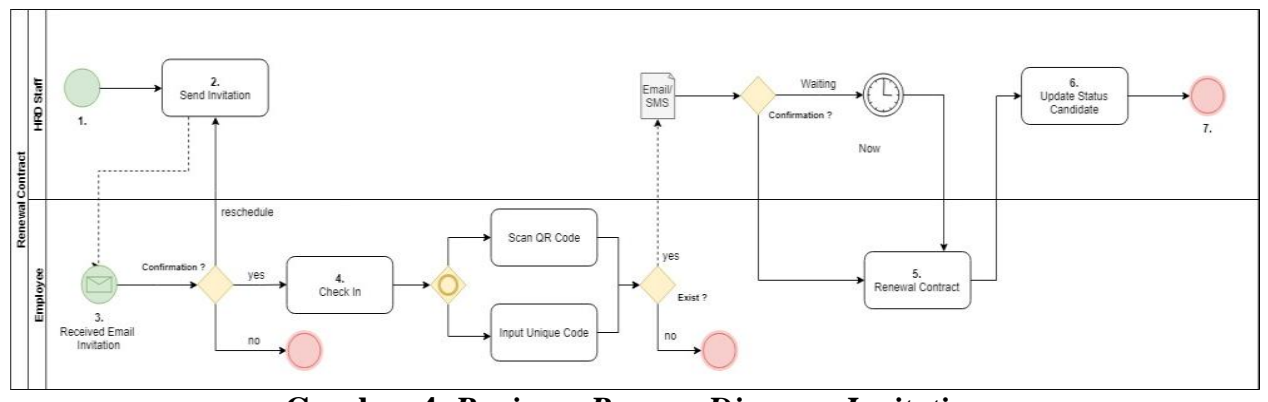

Gambar 4. Business Process Diagram Invitation

Staff HRD akan melakukan input data kandidat employee pada setiap kolom yang disediakan. Setelah semua kolom terisi, maka data kandidat employee di submit untuk menjadi invitation berupa email serta QR Code yang akan digunakan untuk check in. Kandidat employee mendapatkan email untuk konfirmasi kehadiran interview beserta QR Code yang akan digunakan untuk check in. Kemudian kandidat employee akan datang ke kantor MII dan melakukan check in, kandidat dapat melakukan check in dengan 2 cara yait Scan QR Code yang terdapat pada email, atau input Unique Code yang terdapat pada email invitation. Apabila QR Code berhasil di pindai maka sistem secara otomatis akan mengirim email serta SMS ke Staff HRD yang bersangkutan. Kandidat melakukan interview. Staff HRD mengubah status interview kandidat menjadi "Done". Apabila dalam 1 Jam setelah kandidat selesai melakukan interview (sesuai jadwal yang telah di input dalam sistem) belum ada perubahan di sistem, maka sistem akan mengirimkan email reminder kepada staf HRD untuk mengubah status kandidat tersebut ke dalam sistem. 


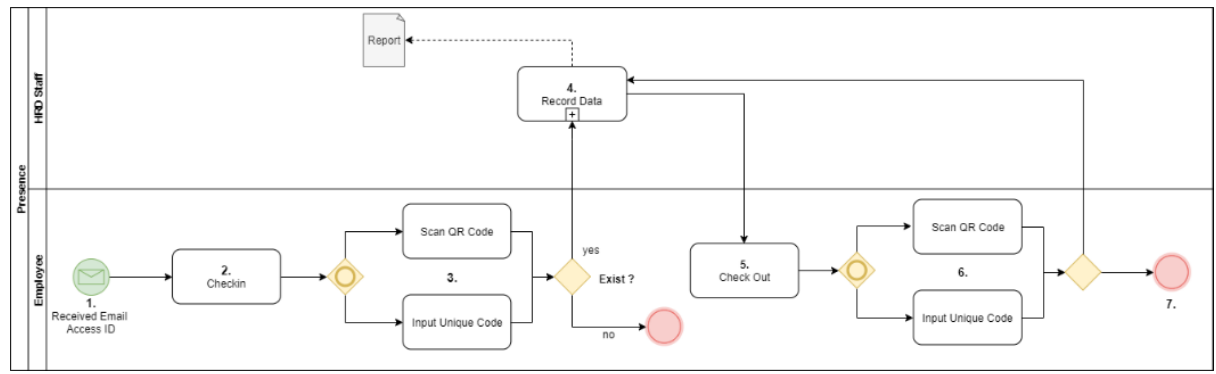

Gambar 5. Business Process Diagram Presence

Employee datang ke kantor MII dan melakukan check in. Employee dapat melakukan check in dengan 2 cara Scan QR Code yang terdapat pada email, atau input Unique Code yang terdapat pada email. Staff HRD mendapat data kehadiran dari setiap employee. Employee akan meninggalkan kantor MII dan melakukan check out. Employee dapat melakukan check in dengan 2 (dua) cara Scan QR Code yang terdapat pada email, atau input Unique Code yang terdapat pada email.

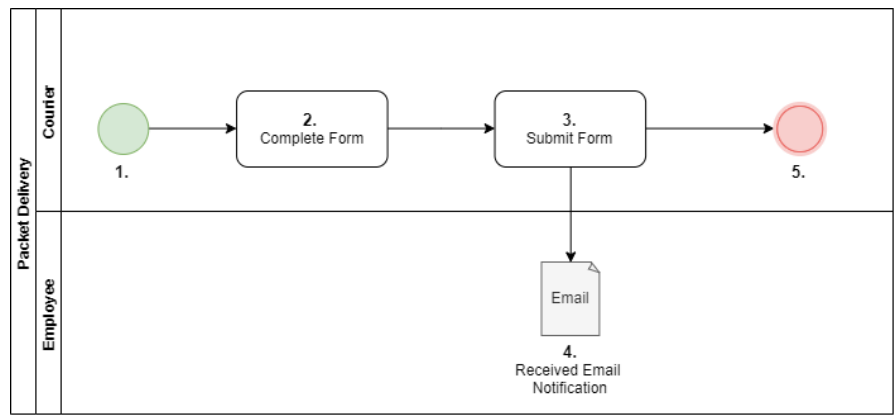

Gambar 6. Business Process Diagram Packet Delivery

Courier akan memilih menu packet delivery, kemudian akan mengisi form yang tersedia. Kemudian courier akan mensubmit form tersebut dan secara otomatis karyawan yang bersangkutan akan mendapat email notifikasi mengenai packet tersebut.

\section{HASIL DAN PEMBAHASAN}

Berdasarkan perancangan sistem yang ada maka dilakukan implementasi aplikasi Guest Self Service khususnya pada penggunaan teknologi QR Code. Implementasi ini diharapkan dapat sesuai dengan kebutuhan pengguna sehingga dapat menyelesaikan permasalahan yang ada. 


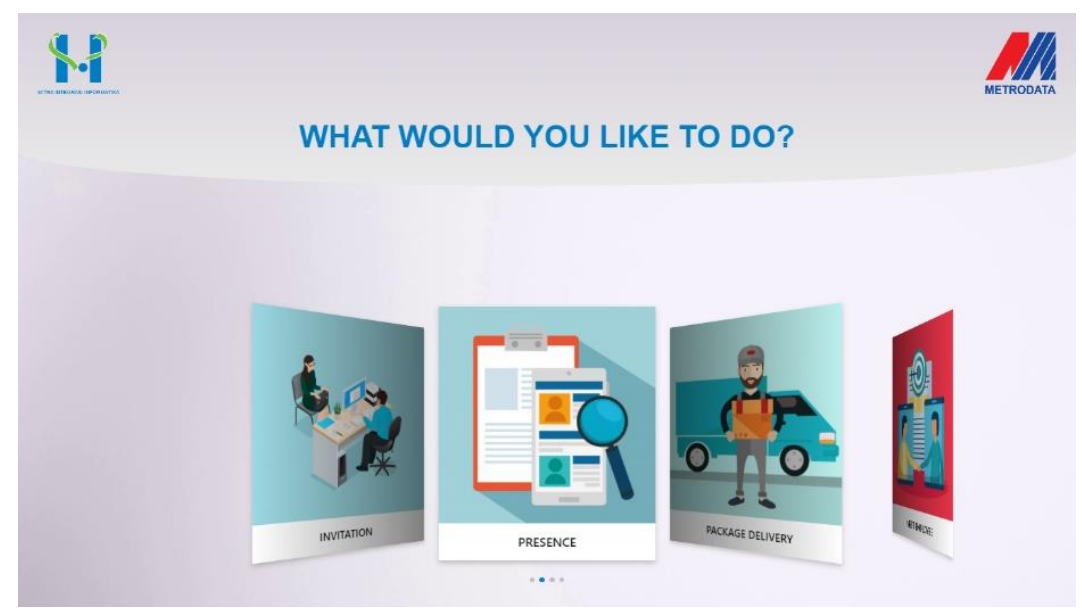

Gambar 7. Menu Landing Page Guest Self Service

Gambar 7 menunjukkan tampilan menu Landing Page Guest Self Service. Halaman ini menyajikan pilihan menu untuk fungsi yang ada di Guest Self Service seperti Invitation, Presence, Packet Delivery dan Meet Employe. Landing Page ini dibuat semenarik dan sesimpel mungkin agar guest yang datang dapat dimanjakan dan dimudahkan dengan tampilan yang elegan.

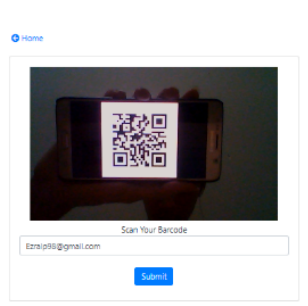

\section{Scan Your QR Code}

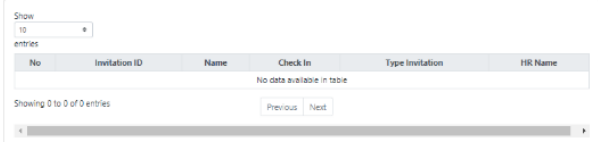

\section{Gambar 8. Menu Invitation Guest Self Service}

Gambar 8 menunjukan tampilan halaman Invitation. Halaman ini digunakan untuk scan invitation berupa QR code atau bisa juga dengan memasukan unique code pada form input yang disediakan. Data mengenai invitation tersebut kemudian akan ditampilkan ke dalam tabel sebagai history. Terdapat 2 fungsi tambahan pada tabel yaitu show entries dan sorting data disetiap kolomnya. 


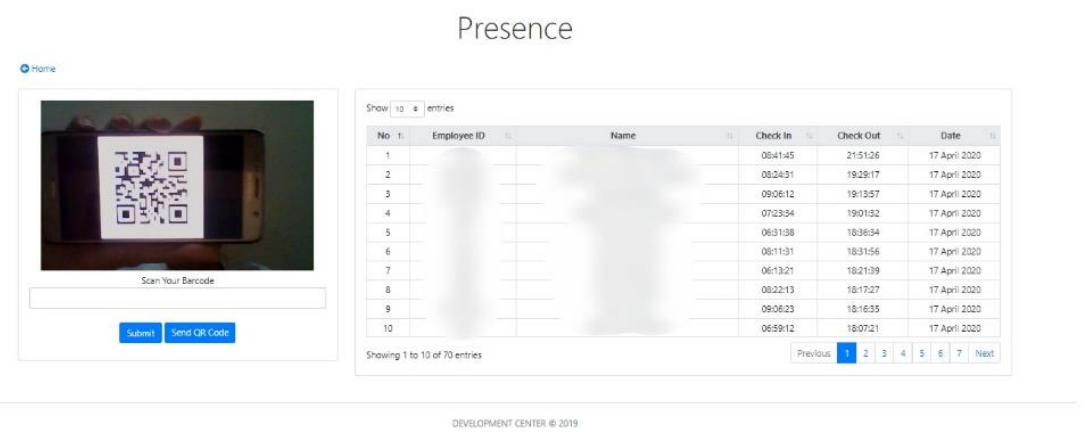

Gambar 9. Menu Presence Guest Self Service

Gambar 9 menunjukan tampilan halaman presence. Halaman ini digunakan untuk melakukan absen untuk karyawan maupun peserta bootcamp dengan cara scan QR Code atau bisa juga dengan memasukan unique code pada form input yang disediakan. Data absen tersebut kemudian ditampilkan ke dalam tabel sebagai history. Terdapat 2 fungsi tambahan pada tabel yaitu show entries dan sorting data di setiap kolomnya.

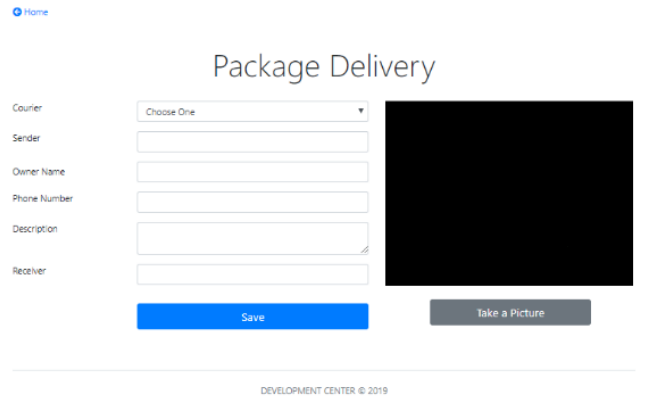

Gambar 10. Menu Package Delivery

Gambar 10 menunjukan tampilan halaman Package Delivery. Halaman ini digunakan untuk mendata paket yang dikirimkan oleh courier dengan mengisi form auto complete yang sudah disediakan. Terdapat button Take a Picture yang digunakan untuk mengcapture paket yang dikirimkan oleh courier. 
Implementasi QR Code pada aplikasi Guest Self Service ini terdiri dari dua tahap yaitu tahap pembuatan QR Code dan tahap pemindaian QR Code yang telah dibuat.

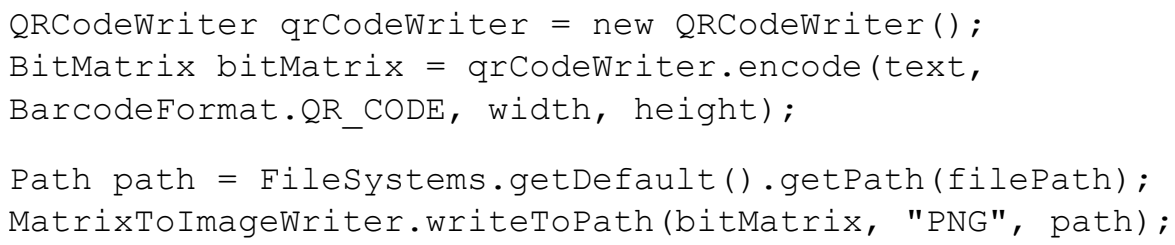

Pembuatan QR Code dari sebuah inputan String menjadi pola bar dilakukan dengan cara memanggil method encode() yang terdapat pada libary Zxing dan menjadikan String text, sebagai input parameternya.

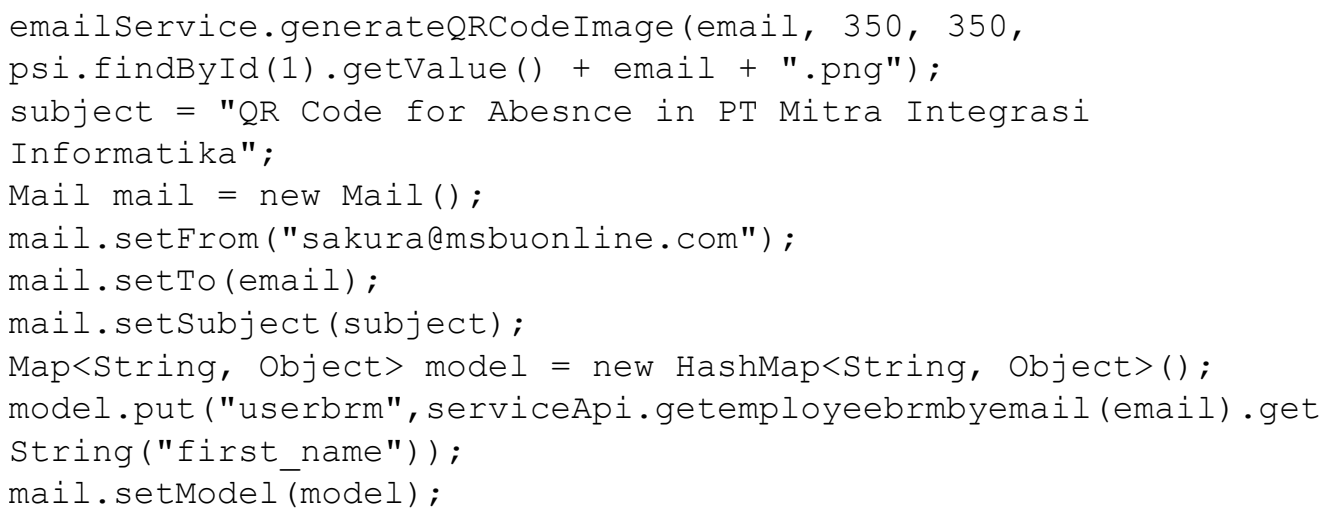

QR Code pada aplikasi Guest Self Service ini dibuat dengan ukuran 350x350 pixel dalam format .png. QR Code yang sudah dibuat tadi kemudian dikirim melalui email dengan menggunakan email service.

Pemindaian QR Code dilakukan dengan memindai gambar QR Code yang telah dibuat dengan library ZXing untuk pembacaan QR Code. Pemindaian dilakukan dengan mengaktifkan kamera perangkat yang kemudian dapat digunakan untuk memindai gambar QR Code. Hasil pemindaian kemudian didapatkan hasil berupa email atau Employee ID. Email atau employee ID tersebut kemudian dicocokan dengan data di database untuk dilakukan verifikasi. Jika verifikasi berhasil maka employee telah berhasil melakukan absen.

Pengujian sistem dilakukan untuk memastikan sistem dapat berjalan dengan baik dan sesuai dengan kebutuhan pengguna. Pengujian dari sisi developer atau peneliti dilakukan dengan metode Black Box Testing untuk memastikan setiap fungsi yang ada pada sistem berjalan dengan baik dan sesuai kebutuhan [8]. Hasilnya ada di Tabel 1.

Tabel 1. Hasil Black Box Testing

\begin{tabular}{lllc}
\hline \multicolumn{1}{c}{ Fungsi } & \multicolumn{1}{c}{ Skenario } & \multicolumn{1}{c}{ Hasil } & Validitas \\
\hline Generate QR Code & $\begin{array}{l}\text { Sistem menggenerate email atau } \\
\text { employee ID menjadi QR Code }\end{array}$ & $\begin{array}{l}\text { Email atau employee ID berhasil } \\
\text { digenerate menjadi QR Code }\end{array}$ & $\checkmark$ \\
Send QR Code & $\begin{array}{l}\text { Sistem mengirim QR Code } \\
\text { melalui } \text { email yang diinputkan }\end{array}$ & QR Code berhasil dikirimkan & \\
Pembacaan QR Code & $\begin{array}{l}\text { Sistem dapat membaca serta } \\
\text { menyimpan data berupa hari dan }\end{array}$ & $\begin{array}{l}\text { Data berhasil disimpan di database } \\
\text { dan ditampilkan ke tabel }\end{array}$ & \\
& $\begin{array}{l}\text { tanggal saat melakukan scan QR } \\
\text { Code }\end{array}$ & &
\end{tabular}




\begin{tabular}{lll} 
Absence Check In & $\begin{array}{l}\text { Sistem menyimpan data untuk } \\
\text { Check In saat pertama kali } \\
\text { melakukan scan QR Code }\end{array}$ & $\begin{array}{l}\text { Data berhasil disimpan di database } \\
\text { dan di tampilkan ke tabel }\end{array}$ \\
Absence Check Out & $\begin{array}{l}\text { Sistem menyimpan data yang } \\
\text { paling akhir diinputkan hingga } \\
\text { berganti hari }\end{array}$ & $\begin{array}{l}\text { Data berhasil disimpan dan } \\
\text { diupdate di database dan di } \\
\text { tampilkan ke tabel }\end{array}$ \\
\hline
\end{tabular}

\section{KESIMPULAN}

Berdasarkan hasil penelitian dan pengujian dapat disimpulkan bahwa implementasi web Guest Self Service untuk absen yang memanfaatkan teknologi QR Coode dan dibangun menggunakan framework Spring Boot dapat membantu mengelola pendataan tamu dan karyawan pada PT. Mitra Integrasi Informatika. Dengan adanya aplikasi ini proses mendata tamu dan karyawan dapat dilakukan dengan mudah melalui Scan QR Code.

Proses pembuatan QR Code dilakukan dengan cara mengkonversi inputan karakter menjadi pola QR Code, sedangkan proses pembacaan QR Code dilakukan dengan cara menterjemahkan kembali pola QR Code tersebut menjadi format karakter dan dikirim ke server untuk proses pengecekan untuk ditampilkan ke tabel riwayat absen.

\section{DAFTAR PUSTAKA}

[1] A. SN and R. A. Azdy, Implementasi Scrum Pada Pengembangan Software Terdistribusi, p. 6, 2012.

[2] Y. Monden, Sistem Produksi Toyota, Jakarta: Pustaka Binaman Pressindo.

[3] A. Nuryanto and W. . A. Utomo, "Pembuatan Self-Service System di Dapoer Cha Cha Resto," vol. 22 No. 1, 2016.

[4] M. T. Nuddin and D. L. Fithri, "Sistem Absensi Asisten Dosen Menggunakan QR Code Scanner Berbasis Android Pada Program Studi Sistem Informasi Universitas Muria Kudus," 2015.

[5] M. . L. Meuter, A. L. Ostrom, R. I. Roundtree and M. J. Bitner, "Self-Service Technologies: Understanding Customer Satisfaction with Technology-Based Service Encounters," Journal of Marketing, vol. 64, pp. 50-64, 2000.

[6] A. Pulungan and A. Saleh, "Pemanfaatan QR Code Dalam Memudahkan Proses Absensi Siswa Berbasis Apikasi Mobile," Jurnal Masyarakat Telematika dan Informasi, vol. 10, pp. 1-12, 2019.

[7] F. Ishami, R. I. Rokhmawati and M. C. Saputra, "Pengembangan Sistem Self-Service Reservation pada Everyday Smart Hotel Malang Menggunakan Customer Relationship Management (CRM) Operasional Modul Sales Force Automation dan Service Automation," Jurnal Pengembangan Teknologi Informasi dan Ilmu Komputer, vol. 2, pp. 632-640, 2018.

[8] M. S. Mustaqbal, R. F. Firdaus and H. Rahmadi, "Pengujian Aplikasi Menggunakan Black Box Testing Boundary Value Analysis (Studi Kasus : Aplikasi Prediksi Kelulusan SNMPTN)," Jurnal Ilmiah Teknologi Informasi Terapan, vol. 1, pp. 31-36, 2015.

[9] C. E. Prastio and N. Ani, "Aplikasi Self Service Menu Menggunakan Metode Scrum Berbasis Android," Jurnal Petir, vol. 11, pp. 203-220, 2018.

[10] R. Tuloli and I. Mohidin, "Aplikasi Absen Kuliah Menggunakan Kode QR (Quick Response)," JTII, vol. 3, pp. 61-67, 2018. 